\title{
S-II-8 三尖弁閉鎖不全症に対する外科治療の問題点
}

\author{
——手術成績，遠隔成績と DeVega 法の評価—
}

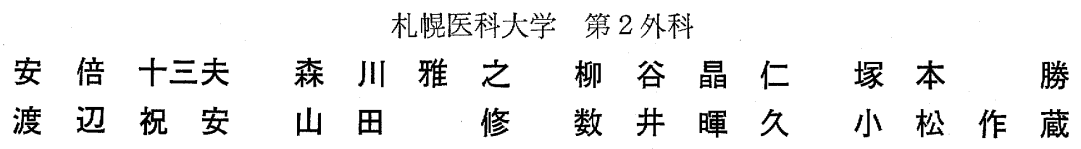

三尖弁閉銷不全（以下 TR と略す）を合併する心疾 患哇重篤症状を伴う症例が多く, 三尖弁に対する手術方 法むまだ確立しておらず，術後に多くの問験点を残して いる1,2).

今回, 著者らは, 教室で過去 10 年間に三尖弁膜症に 対して外科治療を施行した，後天性弁膜症に合併した 81 例, 先天性心奇形に伴う 14 例, 合計 95 例飞外科治 療を行ってきたので, 手術成績, 手術方法, 遠隔期での 問験点, 現在, 教室で行っている DeVega 法の評価を 心エコー戝法で行っているので, 本法の問題点について あ報告する。

\section{対象と方法}

1978 年 1 月 1988 年 1 月までの過去 10 年間に, 当教 室で後天性弁膜症に対して手術施行症例は 628 例で，乙 のうち三尖弁膜症に対する手術例は 81 例 (11\%) であ る. これら症例で，僧帽弁膜症合併は 63 例 (78\%)，大 動脈弁之僧帽弁合併は 18 例 (22\%) である. 先天性心 奇形に合併した三尖弁膜症手術症例は 14 例で, 同年代 における手術例 900 例中 $15 \%$ である.

乙れら三尖弁膜症手術症例の手術時年齡は, 後天性平 均 53 歳, 先天性 23 歳である. 術前の NYHA 重症度 分類では, 後天性でIII IV 度 78 例 $(96 \%)$, 先天性 12 例（86\%）であった．また，手術術式別では，後天性で は弁輪形成術（TAP：DeVega 法） 64 例 (85.2\%)，弁 置換 12 例 (14.8\%), 先天性では并置換 6 例, 弁形成術 4 例, DeVega 法 4 例である.

手術は, 全例, 完全体外循環下に, 心停止液併用晶質 ないし血液心筋保護液を用い, 局所心筋冷却を行った。 三尖弁に対する弁輪縫縮術として, DeVega 法に準じ, Rowlett の正常三尖弁輪径 23〜30 mm 大に, 教室で作 成したサイザーを用いて行った。 三尖弁逆流試験とし て, 主肺動脈からピッグティルカテーテルを右室内に留 置し，肺動脈末梢側に遮断錳子を置いて，DeVega 前後 の弁形態と逆流程度の判定を行い, 逆流高度の症例には
弁置換を行った. 弁置換症例は，後天性弁膜症では 12 例に用い（機械弁 8 例, 生体弁 4 例), 先天性 6 例（5 例に生体弁，1例に機械弁）に用いた。

また，二次性 TR に対する DeVega 法による TAP の効果を, TR を放置した例と比較検討した，方法とし て, パルスドプラ法により晾断した，二次性 $\mathrm{TR}$ 症例 36 例住対し, DeVega 法施行した 15 例（I 群）之右房 平均圧が $10 \mathrm{mmHg}$ 以下で放置例 21 例（II群）として 比較検討した。

\section{結果と成績}

\section{1. 手術成績と遠隔成績}

手術成績と遠隔成績は表 1 亿示すが，僧帽弁を合併し 三尖弁に外科治療症例は 63 例で手術死は 7 例 $(12.5 \%)$ で，このうち，MVR または ReMVR+TAP での手術 死 6 例之最屯多く, MVR +TVR 症例は 11 例で手術死

表 1 知患別手術成績と遠隔成績

(1978. 1. -1988. 1.)

\begin{tabular}{|c|c|c|c|c|}
\hline \multirow{2}{*}{\multicolumn{2}{|c|}{ Procedure }} & \multirow{2}{*}{$\begin{array}{l}\text { No. of } \\
\text { Patients }\end{array}$} & \multicolumn{2}{|c|}{ Results (Deaths) } \\
\hline & & & Early (\%) & Late (\%) \\
\hline \multirow[t]{6}{*}{$M+T$} & MVR+TAP & 37 & 4 & 2 \\
\hline & ReMVR+TAP & 10 & 2 & \\
\hline & $\mathrm{OMC} / \mathrm{MAP}+\mathrm{TAP}$ & 5 & & \\
\hline & MVR+TVR & 6 & & \\
\hline & ReMVR+TVR & 5 & 1 & \\
\hline & & 63 & $7(12.5)$ & $2(3.1)$ \\
\hline \multirow[t]{5}{*}{$A+M+T$} & $\mathrm{AVR}+\mathrm{MVR}+\mathrm{TAP}$ & 13 & 1 & 1 \\
\hline & $\mathrm{AVR}+\mathrm{OMC}+\mathrm{TAP}$ & 3 & & \\
\hline & $\mathrm{AVR}+\mathrm{MAP}+\mathrm{TAP}$ & $P$ & & \\
\hline & $\mathrm{AVR}+\mathrm{MVR}+\mathrm{TVR}$ & R 1 & & \\
\hline & & 18 & $1(5.6)$ & $1(5.6)$ \\
\hline \multirow[t]{6}{*}{$\mathrm{CHD}$} & VSD+TVR & 4 & & 1 \\
\hline & VSD+TAP & 3 & & \\
\hline & $\mathrm{TOF}+\mathrm{TAP}$ & 3 & & \\
\hline & TOF+TVR & 2 & & 1 \\
\hline & $\mathrm{ASD}+\mathrm{TAP}$ & 2 & & \\
\hline & Total & 14 & 0 & $2(14)$ \\
\hline
\end{tabular}


1 例であった，遠隔死は 2 例（3.1\%）認めた.

また，大動脈弁（A弁）十僧帽弁（M弁）を合併した 3 弁矣患化対する手術成績は 18 例で，早期死 1 例（5.6 $\%)$ ，晚期死 1 例である.

先天性心奇形汇対する心内修復後の TR 発生は，教室 に抒ける過去 10 年間の先天性開心術症例 850 例中 14 例 (1.6\%) である，疾患別では，VSD 合併 7 例，ファロ 一根治前後 5 例, 高齢者（80 歳以上） ASD 亿合併し た 2 例に対し，弁置換 6 例之弁形成 4 例，并輪縫縮 4 例 であった．手術死亡は認めず，2例に遠隔死を認めた。

これら，外科治療症例の早期および晚期死亡原因につ いてみると，早期死の原因は，術前 Cardiac cachexia を伴った．重症例が術後に抵心拍出量症候群（LOS）を 伴い他の主要臟器障害に移行した症例を多く認めた。そ のほか, 再々手術後の出血, 不整脈死, 敗血症, 多臟器 障害 (MOF) であった，遠隔期死は，人工弁に基因する 之思われる突然死 2 例，心不全，不整脈死，脳塞栓各 1 例である。

\section{DeVega 法の術後評価}

現在, DeVega 変法は, Rowlett の正常三尖弁輪径 に準じ 23 30 mm 大に縫縮し，今回心ェコ一図にて検 索した症例 15 例は弁輪径平均は $28.4 \pm 1.1 \mathrm{~mm}$ であっ た. また，放置例 21 例では平均 $34.7 \pm 6.4 \mathrm{~mm}$ であっ た.

断層心エコー図から，呼気静止時のIVC，肝静脈径 (HV), パルスドプラ一法 (PD 法) より, 三尖弁逆流 到達距離（TRD），ドプラ断層法から，三尖弁逆流面積 (TRA), 心臟カテーテル法より, 右房平均圧 (m-RA), 右房 $\mathrm{v}$ 波を術前，術後 1 力月につき比較検討した。

1）三尖弁逆流面積と逆流到達距離の変化（図 1) まず，逆流距離 (TRD) はI群 (DeVega 施行) で, 術前平均 $42.6 \pm 12.2 \mathrm{~mm}$, II 群放置例の術前 $22.9 \pm 7.6$ $\mathrm{mm}$ に比し, 有意に高く, 術後 1 力月で $8.5 \pm 10.2 \mathrm{~mm}$ と有意任低下し，II群では， $22 \pm 13 \mathrm{~mm}$ と高值を示し， I II群間に有意差を認めた，逆流面積（TRA） は，I群 の術前 $554 \pm 260 \mathrm{~mm}^{2}$ とII群の術前 $152 \pm 95 \mathrm{~mm}^{2}$ に比 し，有意化高値を示した，術後 1 カ月では，I群 $58 \pm$ $70 \mathrm{~mm}^{2}$ と有意に低下し，II群は $130 \pm 131 \mathrm{~mm}^{2}$ で術前 と変化を認めなかった。 また, DeVega 施行 15 例中, 13 例で TR が改善し, このうち 7 例で TR は消失し た。また，2例では TR が残存ないし悪化を示した。

IVC の径は, I 群術前 $20.4 \pm 4.5 \mathrm{~mm}$ で, II 群の 15. $3 \pm 3.8 \mathrm{~mm}$ に比し，有意に高く，術後 1 力月で 16.7 $\pm 2.7 \mathrm{~mm}$ と有意に低下した。一方，II群では，14.4士
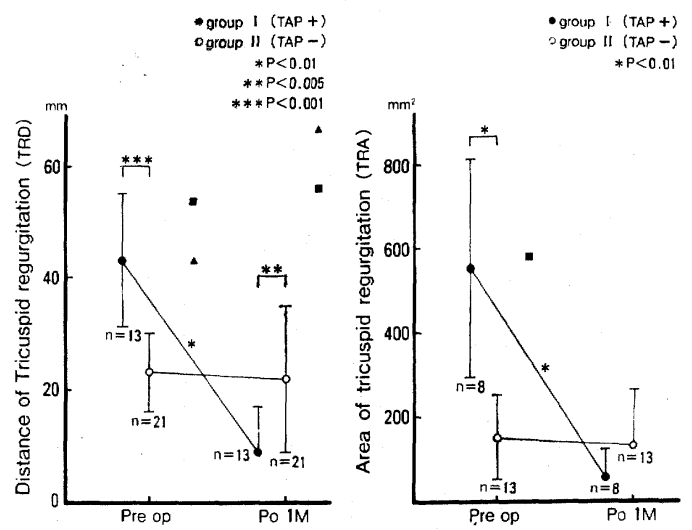

図 1 DeVega 法施行 (Group I) と TR 放置例 (Group II)のドップラー断層法による三尖弁逆流距離, 逆流 面積比較検討

$3.6 \mathrm{~mm}$ と変化を示さなかった，また，HV 径は，両群 とも有意差は示さず，I群でII群に比し，術前後高値で 経過している.

2）平均右房圧（m-RA），右房 $\mathrm{v}$ 波の術前後の変動

RAv 波はI群，術前 $9.7 \pm 4.4$ とII群の $6.1 \pm 2.2$ $\mathrm{mmHg}$ 亿比し, 高く, 術後は両群とも低下するも有意 差はなく，m-RA は，I群の術前 $7 \pm 3.8 \mathrm{mmHg}$ でII 群 $4.3 \pm 1.8 \mathrm{mmHg}$ 亿比し, 有意化高く, 術後は I 群 で $5.6 \pm 1.8 \mathrm{mmHg}$ と有意飞低下した。群は差を認 めなかった。

\section{3. 疾患別，DeVega 法と三尖弁置換 (TVR) の比較} 検討

$\mathrm{M}$ 弁+ TAP (13 例), A 弁 $+\mathrm{M}$ 弁+ TAP (8 例), $M$ 弁 $+T V R$ （7例）について, 術前後の血行動態につ いてみると, 図 2 に示すが, m-RAP は, 術前, MVR +TAP 群に比へ，TVR 群, 三尖群は有意に高く, 術後 は 3 群とも有意に低下を示した。平均肺動脈圧，平均肺 動脈楔入圧は，術前は三弁矣患で高く，術後も $\mathrm{m}-\mathrm{PCWP}$ は三弁疾患で，MVR+TAP に比し高值を示した（ $p<$ 0.05). 心拍係数 (CI) は， 3 群と屯有意任改善し，弁 置換 (TVR) 群の改善度は良好であった。

心胸郭比 (CTR), NYHA 重症度の変動では, CTR は, 術前の三弁疾患で MVR+TAP 群に比し, 有意に 高く，術後では三群とも有意に改善したＮNYHA の変 動では，MVR+TAP 群では術前平均 2.8 0 0.6, MVR

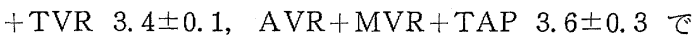


れぞれ $1.2 \pm 0.2 ， 1.9 \pm 0.41 .7 \pm 0.2$ と有意に改善を 認めている。 




図 2 三尖弁膜症に対する手術術式別 (MVR+TAP: 13 例, MVR+TVR 7例, AVR+MVR+TAP 8例) の術前後の血行動態の変動

\section{4. 検討遠隔期の問題点}

術後の経過観察期間は 1 力月 10 年 (平均 57 力月) であり，遠隔期死亡は後天性 5 例 $(5.7 \%)$, 先天性 2 例 (敗血症，リズム死）である. DeVega 施行後の再手術 例は 2 例で， 1 例に術後 6 年目に TVR（機械弁）を 施行している. 他の1例は生体弁機能不全 (PTF) で ReMVR のみを施行している. また, ReMVR 症例は 10 例で, 初回, 生体弁使用 9 例で PTF による TR で TAP 施行した.

術後の生存率は MVR+TAP で 10 年目で $87.5 \pm 4.8$ $\%, \quad$ AVR + MVR + TAP $86.7 \pm 8.7 \%, \quad$ MVR + TVR で $80 \pm 12.6 \%$ であり, 三群間では有意差を認めなかっ た.

\section{考案}

三尖弁閉銷不全 (TR) は，僧帽弁膜症の $20 \%$ 前後に 合併し ${ }^{3)}$ ，乙の発生機序として，持続的肺高血圧に対応 し, 右室の拡大にて生ずると考えられ, 僧帽弁病変に対 する修復で右室負荷が消失すれば，TR も消失するとの 報告がみられるが4)，一般には，TR は残存し，悪化し て本疾患の予後を不良にする報告が多い ${ }^{1 \sim 3,5)}$.

今回，著者らは，僧帽弁膜症に合併した後天性 TR 81 例之先天性心奇形飞合併した TR 14 例, 計 95 例に つき検討し, 後天性の TAP 施行 69 例で, 手術死 7 例 (10\%), TVR 12 例では 1 例 (8.3\%) の手術死亡を認 めたが，先天性疾患では手術死を認めず，満足すべき結 果が得られ, 早期死亡例は心筋障害, 他臟器障害高度の
症例であった。

本病態の診断法として, 心カテーテル, 造影所見と最 近では心エコー眓法の導入により, 三尖弁逆流の程度が 明確となってきている. 三尖弁手術適応として, 右房平 均圧 $10 \mathrm{mmHg}$, 右室造影飞て中等度以上の逆流 ${ }^{2}$, 心 エコー図で逆流到達距離 $30 \mathrm{~mm}$ 以上, 逆流面積 400 $\mathrm{mm}^{2}$ 以上を基準としている.

次に, 本症に対する術式として, 弁形成, 并輪縫縮, リングによる弁輪形成拉よび弁置換が行われているが, 弁形成は主として乳頭筋断裂が行われ，著者らあファロ 一根治手術後の乳頭筋断裂，伸展が高度の症例飞施行し 良好な結果を得ている ${ }^{6)}$. 弁輪縫縮術としては, Kay 法 と DeVega 法が用いられているが両者で差がないとの 報告がみられ7), また DeVega 法の術後血行動態の検 索2) 之長期予後5) からあ良好な報告がみられている。

今回, 自験例での検索でも, DeVega 施行例と TR 放置例を術前後の心エコー図からと心カテーテル検索 で，TR に対し DeVega 施行例では 15 例中 13 例（87 \%) 飞改善し，7例（46\%）飞術後 TR の消失を認め た。 また，僧帽弁の修復にあかかわらず，TR 放置群で は，術後の心エコー図所見からは TR 病変部の残存を みとめた，本症に対する弁置換症例は 12 例に行い手術 死 1 例（8.3\%） と症例は少数ではあるが, TAP 症例 69 例中手術死亡 7 例 (10\%) 飞比し差は認めていない, 術後の血行動態であ TVR 施行例では TAP に比し, 良好な改善が得られている。 また，遠隔成績についてみ ても，TVR 5 年の生存率は $80 \%$ で, TAP 症例 10 年 
の $86 \%, 87 \%$ に比べて劣るが，両者での有意差は認め ていない、しかし, 人工弁使用での利点として, 弁使用 による TR の完全消失, MR が再発しても再度 TR が生じないとと, 一方, 弁置換による不利な点として, 血栓形成, 弁機能不全, 組織の過剩形成による狭窄, 抗 凝血療法による出血の危険性があげられる.

以上の教室に扔ける TR に対する外科治療経験から， 中等度加高度の TR 亿対して, 弁輪縫縮術を第一選 択とし, 三尖弁中隔尖の肥厚, 伸展など高度の病変と三 尖弁全体の逸脱を伴う症例には人工弁による弁置換も考 慮される.

\section{おわりに}

教室で 1978 年 1 月〜 1988 年 1 月までの 10 年間に三
尖弁病変部に対して外科治療を施行した 95 症例につ き, 手術術式別手術成績, 遠隔成績を検討し報告した. また，本症に対する弁輪縫縮術の有用性を心カテーテル 検査, 心エコー四所見から述べた，また，TAP 術後の 再 TR 症例, 高度荒廃した三尖弁に対しては弁置換手 術の必要性を述べた。

文 献 1) Haerten, K. et al.: Circulation 58 (Suppl. 1) : 28, 1978. 2) Simon, R. et al.: Circulation 62 (Suppl. 1) : 52, 1980. 3) Boyd, A. D. et al.: J. Thorac. Cardiovasc. Surg. $68: 344,1974 . \quad$ 4) Braunwald, N. S. et al.: Circulation 35, 36 (Suppl. 1) : 63, 1967. 5) Chidambaram, M. et al.: Ann. Thorac. Surg. $43:$ 185, 1987. 6) Abe, T. et al.: J. Cardiovasc. Surg. 26:568, 1985. 7) Peterffy, A. et al.: Scand. J. Thorac. Cardiovasc. Surg. $14: 247$, 1980 . 